\title{
Student's view of education as the merit and private economic goods
}

\author{
Vera Anatol'evna Gnevasheva \\ Institute for the Fundamental and Applied Researchers, Moscow University for the Humanities, Moscow, Russia
}

\section{Email address:}

vera_cos@rambler.ru

\section{To cite this article:}

Vera Anatol'evna Gnevasheva. Student's View of Education as the Merit and Private Economic Goods. Science Journal of Education. Vol. 2, No. 5, 2014, pp. 141-145. doi: 10.11648/j.sjedu.20140205.11

\begin{abstract}
Economic theory defines the market of the higher professional education as an intellectual property due to a system where product demand is formed by the higher education institutes. It is presently formed as the combined system of the state and non-state or private forms. The emergence of fee-based forms of education involves the formation of market relations and the determination of the price of such services. The higher professional education market arose in Russia together with the reform of other spheres of economic life in order to create out education, and also as the merit and the private economic goods. But the social importance of the role of these goods cannot identify education as the pure product of the market. The possibility of establishing education as the market product is formed in connection with the inseparability of the existing system of educational services from the labor market as the end user.
\end{abstract}

Keywords: Higher Professional Education, Market of the Goods, Merit and Private Economic Good, Labour Force, Youth

\section{Introduction}

The higher professional education market arose in Russia together with the reforms of other spheres of economic life in order to reveal the professional education as the merit and private economic goods and the investment resource with the certain rate of benefits. Due to the results of the Russian monitoring research, the demand function for the benefit from the investments in the higher professional educational is characterized by the high elasticity of demand due to expected income. Rational choice of the consumer of this good of higher professional education is characterized by the expectation of such probably economic features as: the future income, the future job of interest, the prestige of the diploma, the prestige of the university, etc. [1]. All these allow us to consider the contemporary good of the educational services of the higher professional education for its consumers due to the point of economic theory as the 'attributive good of luxury' with derivative benefits.

\section{Main Theoretical and Empirical Points}

Market of the educational services of the higher professional education was borne by both economic and social burden. Substantial importance in shaping the education market is to reveal the concept of 'economic benefit' to the investment resource - educational services of higher professional education, and understand the good - education services of the higher professional education as the merit and private economic good [2].

Terminological difficulty in determination of the education market arises due to the need of good 'educational services of higher professional education' definition as the merit and private economic due to the expected social and economic benefits.

Educational services of the higher professional education are economically descriptive due to the method of funding, as the merit good, which ensures by the state and the private economic good, the demand for which is defined due to the current purchasing power of the population [3].

Today in Russia the proposal of educational services of higher professional education is proximately $58.5 \%$ provided by the state and municipal institutes (universities, academies) of higher professional education. Higher professional education is almost $50 \%$ provided by the Russian State (financed by the budget and though free for the students). Being the merit good, educational services of higher professional education (HPE) are characterized by the features of non-exclusive consumption of and non-competitiveness. The economic feature of the defined merit good as the "not 
competitive' (what is the feature of the all merit goods) is formed due to the accessible supply for this good of educational services of the higher professional education, what presently draw a picture of over supply of the good to the consumption demand, that creates the competition among the producers of this good (the universities), but not among the consumers (students).

The other feature of the merit good and also partly of the educational services of the higher professional education in terms of definition as the merit good which is non-exclusive consumption can only be limited today in Russia by the results of the school state exam, but the determined barrier of its pass is allow to ignore this and define now the good of the educational services of the higher professional education as proximately characterized by the merit good's feature as the 'non-exclusive consumption'.

Defining educational services of higher professional education as the private economic good, it's useful to consider the market of educational services as the mechanism of supply and demand.

The level of family welfare of enrollees can be examined by analyzing the statistical data on the population of the Russian Federation in respect of their generated consumer demand for educational services of higher professional education.

Thought we view the object in the framework of Federal districts for criteria:

- average income

- consumer costs per capita on average

- the average monthly nominal wages

- the price range of the cost of educational services of higher professional education (minimum - maximum price on the same programmers of higher education).

It's investigated here the educational and cost policy of the universities of higher professional education in the regional centers of Russian Federation. Statistical data of the research is formed from the following massive:

1. the official statistics of the Federal States of Russia, formed by the State Committee of the Statistics (URL: http:// www.gks.ru)

2. the results of the monitoring research 'Russian Institute through the Eyes of Students' which was held in the period 2003-2013 by the Centre of Youth Sociology Institute for the Fundamental and Applied researches by the leadership of the author (the project was financed by the Russian Fund for the Humanities).

For the analysis of the consumer ability of the Russian population for the 'educational services of the higher professional education', were considered the data of the Russian Federation in the framework of the federal districts, for the following criteria: per capita income of the population, consumer costs on the average per capita; average monthly nominal accrued wages; price range of the cost of educational services to full-time students in high schools in central cities of the Russian regions.

Let us see the availability of the good 'educational services of the higher professional education' by comparing the proportion of fee-paying students to the average data of the population with the middle due to the region of Russia, as well as to the level of poverty in the Russian Federation for the period 2000-2009. This analyses may allow to reveal that the situation of the poverty in Russia according to their ability of the good 'educational services of the higher professional education'. In theory, it can be assumed that the poor people can be defined as a group to whom there is less availability to the 'educational services of the higher professional education' than the others income groups (Table 1).

Table 1. Data for the ANOVA to define the situation of the poverty in Russia according to their ability of the good 'educational services of the higher professional education'

\begin{tabular}{llllll}
\hline & $\begin{array}{l}\text { Number of Students } \\
\text { (thousands of } \\
\text { people) (official } \\
\text { statistics of RF) }\end{array}$ & $\begin{array}{l}\text { Number of Students who } \\
\text { pay for the education } \\
\text { (thousands of people) } \\
\text { (official statistics of RF) }\end{array}$ & $\begin{array}{l}\text { Proportion of the } \\
\text { students in the system of } \\
\text { paid professional } \\
\text { education as the service } \mathbf{Y}\end{array}$ & $\begin{array}{l}\text { Average income of } \\
\text { population per } \\
\text { capita in month } \\
\text { (rub) } \mathbf{X}_{\mathbf{1}}\end{array}$ & $\begin{array}{l}\text { Proportion of population } \\
\text { with the income less than } \\
\text { the subsistence minimum } \\
\text { (percentage of total) } \mathbf{X}_{\mathbf{2}}\end{array}$ \\
\hline 2000 & 4270,8 & 1468,8 & 0,343917 & 2281,1 & 29 \\
2005 & 5985,3 & 2982,6 & 0,498321 & 811,9 & 17,7 \\
2006 & 6133,1 & 3143,7 & 0,512579 & 10196 & 15,2 \\
2007 & 6208,4 & 3276,8 & 0,527801 & 12602,7 & 13,3 \\
2008 & 6214,8 & 3356,2 & 0,540033 & 14940,6 & 13,4 \\
2009 & 6135,6 & 3371,7 & 0,549531 & 16856,9 & 13,2 \\
\hline
\end{tabular}

Due to the data (Table 1) and by means of the ANOVA we've got the following function (1):

$$
\mathrm{Y}=0,68+(8,94 \mathrm{E}-07) \mathrm{X} 1-0,0117 \mathrm{X} 2
$$

where $\mathrm{Y}$ - is the proportion of the students in the system of paid professional education as the service; $X_{1}$ - is the average income of population per capita in month (rub); $\mathrm{X}_{2}$ - the proportion of population with the income less than the subsistence minimum (percentage of total).

Evaluation of reliability of the regression is defined by the coefficient of multiple determination is the target as $\mathrm{R}_{2}$-statistics, the importance of which for the subject corresponds to $\mathrm{R}_{2}=0.98$, meaning that 98 percents of the variation is due to the factors included in the regression equation, and 2 percents is for the other factors.

Finally, the ANOVA indicates that if the 'poverty' of the population growth, it (the growth of the 'poverty' of the population) will occur much more quickly than would decrease the proportion of students studying on the fee-paying basis.

In other words, the reduction in the incomes not to abandon the people from their investments in the higher professional education on the fee-paying basis, as well as the growth of incomes will not demonstrate the extremely grow in demand 
for the programs of higher professional education, what may mean that the level of the population income and of its distribution is not to influence on the price of the good 'educational services of the higher professional education' in the present circumstances.

Even though the current price range for the educational services of the higher professional education and the level of income of the population, according to the study the functional dependencies and their economic assessment, allows the population to learn and show the availability of the good 'educational services of the higher professional education' supply that fully provides the customer demand.

Generalizing these results, we estimate the availability of good the educational services of the higher professional education considered as a whole for the Russian Federation, due to the results of:

1. ANOVA of the minimal and maximal price of the good educational services of the higher professional education in Russian regions by the factor of influence of consumers through the demand forming;

2. Regression analysis of the relationship of per capita monetary income with the value of consumer spending, a minimum and maximum cost of educational services of the higher professional education viewed for the data of the Russian Federation regions.

Summarizing the above basic types of economic behaviors of consumers good 'educational services of higher professional education', can provide a general typology of dominant types of the socio-economic behaviors of modern Russian youth with respect to investments outcome in education on the following criteria: 'education as the economic good', 'education as the investment resource', 'awareness, perception of education as the economic good and the investment resource'.

Under modern conditions of social development, market mechanisms, economic globalization and the formation of stable relationships 'labor-employee of the new type', it is necessary to describe and analyze the differences of the consumer behavior attitudes toward the private economic good 'educational services of the higher professional education'.

\section{Methodology}

The objectivistic interpretation of value was reflected in Gordon Allport's dispositional conception of person who elaborated "the test of values' study" in the 1930s-1960s. In the Russian sociological school the dispositive concept of personalities have been offered by Vladimir Iadov and it is still accepted by many other researchers.

The works by Oleg Drobnitskii [4] [5] have had a considerable impact on modern Russian researchers of values and value orientations. Recently the traces of the approaches that were accepted in their time by the classics of the Sociological school of Chicago[6] have been noticeable.

During numerous researches on values as a theoretical problem, scholars of different countries, representatives of various scientific schools have expressed many original ideas that allow us to speak of a high level of the elaboration of this matter. The development of the theory of values in modern Russia and in the world as well is expected to continue in the direction of preciseness. The life situation introduces this clarity into it when there are the period of transition and the birth of a new type of civilization - information-oriented. Also they expect the development towards applying of new scientific methods that are being shaped nowadays. In a number of cases it is necessary to follow the path of very general argumentation again in order to define the initial positions of the empirical study.

The specificity of the humanitarian knowledge[7] presupposes that the used terminology will be submitted by some parameters to other rules in comparison with the terminology of so called exact sciences. At this point there is a possibility of polysemy of terms and, in addition, historical mutability of their content. Therefore, it is important to trace down the history of their origin and understanding in various scientific schools. In essence, in the most cases in the humanitarian knowledge a scientist deals not with terms, but with concepts, i.e. with words. In these words aside from a certain content of literal, lexical, figurative, cultural and philosophical meaning there is another image that appears in one's consciousness, and, in its turn, causes an emotional reaction. In contrast to terms, it is very difficult to translate concepts from one language into another. They bear imprints of language history and cultural history. This leads to difficulties in understanding of humanitarian concepts, which were created in different countries. The same concepts can be absolutely identical in diverse cultures seldom.

In our researches on the student youth we study the value orientations, including the value of higher education, on the basis of several indirect characteristics taking the fact that students undergo the active stage of their secondary socialization into consideration. According to the definition by Antonina Kovaleva, socialization is a "process of formation and development of a person that consists in the mastering of social norms, cultural values and models of behaviour during the whole of his/her life, which allows to function in this given society" [8]. This is a double-sided process. One of its sides consists of the fact that society constantly assigns an orientation of socially acceptable behaviour and thinking for a person in different forms, by different means and with various effects. The other side of the process of socialization is personal mastering of these organizing and orientating impulses that society initiates. The result of the socialization is resultant of many differently directed influences. Since we examine the period of life when people are getting education, we can speak only about a certain level of socialization. This level of socialization is exposed to changes because any educational system directly acts as an institute of socialization. Besides, the macro-social environment begins to exert greater influence on a person during student years. This macro-social environment begins to be realized as essential and as a source of orientations and regulator of the choice of an outlook on life. Therefore, in 
many respects value orientations will reflect the accepted in society life orientations, depend on an actual situation and change, sometimes significantly. At the same time value orientations are autonomous enough and can be reproduced from generation to generation not only in order of direct inheritance (through family), but also through mass media and network communication in various social communities[9].

This, in particular, can be confirmed by the monitoring research "Russian Institute of Higher Education Through the Eyes of Students" (the project supervisor, Igor Il'inskii; the supervisor of the IV-VI stages, Valeryi Lukov), which is conducted by Moscow University for the Humanities since the year 2000. The purpose of this project is to reveal the important features of a new type of educational institutions for Russia - the nongovernmental institutes of higher education. In the course of the studies it was very important to found out what were the problems of this new subsystem of the Russian higher education, what it manages to obtain, where its unrealized resources are and what the prospects of its development are. Within the framework of the monitoring two groups of institutes of higher education were compared - State and nongovernmental. Both groups consist of the best Moscow institutes of higher education and institutes of more than ten other Russian cities in the closing stages.

The theoretical elaboration of youth problems, as we understand it, must chiefly follow the path of solution of a number of contradictions, which have been formed in the practice of empirical researches. It is also closely connected with the question about the sociological providing of youth policy, social and youth work and other theoretical scope of scientific knowledge about youth. Many attempts of Russian researchers are aimed at the development of a theory of youth, which would be more adequate to practical purposes. One of such theories is based on the thesaurus approach. Within this theory, the youth is interpreted as a social group consisting of:

(1) People, who assimilate and appropriate a social subjectivity, have the social status of young people and identify themselves as being young;

(2) Thesauruses, which are prevalent in this social group;

(3) The symbolical and physical world, which expresses and reflects these thesauruses.

Such components of the concept and such a connection between them, which is understood as reflection of the social reality, change the very view on sociology of youth.

The thesaurus concept of youth gives an opportunity to make the ways of development of youth social subjectivity clear and find out its controversial traits both as an "objectivity" activity and in facts of self-consciousness, which perform an important regulative function [10].

The circumstance that institutionalized world is not much assimilated by a young person demands compensatory actions from himself, i.e. self-independent and predetermined interaction in peer group. Gradually he is familiarizing with area, rules, and realities of this world. The mechanisms of this familiarization are construction and projecting of social reality. The constructions and projects of a young man can essentially differ from constructions and projects of a "responsible adult" (parents, teachers, etc.) and besides dynamically change. One of the peculiarities of youth milieu is combination of several thesauruses. It causes event-trigger hyperbolization of one of them, which is considered to be the most suitable in this particular life situation.

The general arrangement of social reality construction includes:

(1) adaptation for conditions of environment (trial and mistakes; recognition of parts of environment and rules; alteration of behavior according to rules; understanding and legitimating of a part of environment through "our");

(2) completion of building of reality (symbolization through "good" and "evil", construction of symbolic universe; compensation for the inaccessible; activities for protection of "my world", separation of independence zone);

(3) restructuring of environment conditions (ignoring of unimportant; change of proportions and combinations according to thesaurus; action beyond "my world" in compliance with own symbolic universe).

According to the research, which was not especially devoted to analysis of students' value orientations, we obtained a significant material for sociological generalizations. The most important indicators were outspoken by the students in the form of answers table to the question: "What does a 'good life' mean for you?" In the research that took place in $2013(\mathrm{~N}=3261)$, the answers of the students were distributed in the following way (refer to table 1; the amount of the percent indices exceeds 100 percents since there was a possibility to choose several answers).

The achievement of material well-being is the most wide-spread value orientation in the student community. However, it does not close the belief about a 'good life', in respect of which such values as a 'good family' (73\% in total), a 'good work' (71\%), health (71\%), love (65\%) are still quite significant too. These components form per se understanding of happiness of the contemporary youth and draw the picture of expected life quality in the future.

The tendency toward a spiritual side of their vital activities (family, health, love) is noted in the answers of the students from the regional institutes of higher education. At the same time, both groups have evaluated the factor of possessing political power as less significant. Both groups of the questioned students strive for liberty and independence, safety and security. As regards to the question on altruistic beliefs to live not for myself, but for other people - although they are present in the students' answers, but represent rather small group of the respondents.

\section{Conclusion}

There are deep-rooted traditions of researches on the youth problems in Russia. By their trends and purposes they partly concur with the traditions of the humanities in Europe and America. In Russia in different times -it was the same way in the West - diverse youth concepts had been conveying and continue to express the society's expectations for new generations. This is in a sense a theoretical mirror of the 
natural process of generation change. Under modern conditions these concepts can be reduced to three directions: youth - "no man's land", youth - social danger, youth - hope of society. At the same time youth theories have the mark of the socio-cultural contexts and contexts of the development of the humanities in Russia.

The presented fragments of the research show that the students of all four groups of the institutes of higher education approximately to the same extent are divided in the expression of their own opinions, estimations, viewpoints, level of political activity, etc. It confirms once again that the generalizing word "student body" represents the reality in its exactness. Indeed, the Russian institutes of higher education that were examined during the course of the research are very dissimilar to each other. But student community shows one very significant and firm trend: though there are presented miscellaneous, sometimes diametrically opposite standpoints, but in what that concerns the value orientations and social norms the distribution of answers mainly differs on the gender and age bases, on the specific features of professions they have chosen, in some cases depends on the territorial specificity (that is why we distinguish the city of Moscow from the rest of Russian regions) and almost is not connected with the legal status of a institute of higher education (State or nongovernmental). This is the question of vital importance for the Russian educational system: hitherto the public prejudice exists regarding the nongovernmental institutes of higher education.

If the students of Moscow and other regional institutes of higher education have differences in the value orientations then they are not exceeding the scale to speak of some significant gap between them and what actually separates the capital from the province. Patriotic aspirations are more typical for students from the regions as well as intentions to work in the professional field, willingness to wait for a job placement guaranteed by a native institute of higher education after the graduation, slightly higher level of optimism in the view on the future and others. But as a rule these differences are too insignificant.

Under modern conditions of development of innovative economy the key issue of importance has a matching high-quality characteristics of the workforce needed of the economy and, in particular, the requirements of the labour force in the labour market. Rationality of behaviour of economic agents leads them to realize benefits "higher vocational education" as an investment instrument with the ability to obtain investment income. The monitoring results held by the author from 2001 to the present allow to determine the nature of the investment behaviour and attitudes of young people for the good of the Russian Federation "Higher vocational education" as an investment resources, as well as to determine the opinion of consumer goods in respect of specifying it as a private and public. Despite the multiplicity of positions regarding the definition and evaluation of the elite and even the elite education and the importance of his society as a social elevator formation and predetermination of social strata, the process of globalization, including educational space, and erases obvious differentiated features in the availability of higher education, making the formation of other socio-economic characteristics and remove the accent of social elevator in the stratification of social networks. In a globalize system of values the thesauri of young Russians is becoming more autonomous, expressing the desire and ability to defend their self-identity, and concept formation in the system of value orientations of youth bear the load base values of modern society attributive nature

\section{References}

[1] Vera Gnevasheva "The Role of Education in the Development of Russian Society", Russian Education and Society. Vol. 53, no 4, 2011, pp. 84-96.

[2] Peter Drucker "The Educational Revolution", (Eds.), Social Change: Sources, Patterns, and Consequences. N.Y., 1973.

[3] Lynn Meek "Diversity and Marketization of Higher Education: Incompatible Concepts?", Higher Education Policy, 2000.

[4] Oleg Drobnitskii Mir ozhivshikh predmetov: Problema tsennosti i marksistskaia filosofiia. Moskva, Politizdat. 1967.

[5] Oleg Drobnitskii Tsennost'. In: Filosofskaia entsiklopediia. Moskva, Sovetskaia Entsiklopediia. Vol. 5. 1970.

[6] William Thomas and Florian Znaniecki The Polish Peasant in Europe and America. Vol. I. Boston, Richard Badger. 1918.

[7] Gumanitarnoe znanie: tendentsii razvitiia v XXI veke Pod obshch. red. Valerya Lukova. Moskva, Izd-vo Natsional'nogo instituta biznesa. 2006.

[8] Antonina Kovaleva, "Sotsializatsiia. In: Sotsiologicheskaia entsiklopediia”, 2 Vols, Moskva, Mysl', 2003, pp. 445.

[9] Valeryi Lukov, Vladimir Lukov, "Tezaurusnyi podkhod $\mathrm{v}$ gumanitarnykh naukakh”, Znanie. Ponimanie. Umenie. Vol. 1, 2004, pp. 93-100.

[10] Vera Gnevasheva, "Sotsial'nye i kul'turnye tsennostnye ori-entatsii rossijskoj molodezhi", M, MosGU, 2010, 303 p. 